\title{
Tropical Lightning Current Parameters and Protection of Transmission Lines
}

\author{
Reynaldo Zoro \\ Lightning Research Center (LRC), School for Electrical Engineering and Informatics (SEEI) \\ Institute of Technology Bandung (ITB), West Java - Indonesia \\ zoro@hv.ee.itb.ac.id
}

\begin{abstract}
Lightning Parameters in tropical area have a significant different against Lightning Characteristic measured in the subtropical area. Eight-years measurement has been done at Lightning Measurement Station in Mnt. Tangkuban Perahu to derive the lightning current characteristic in the tropic and it influence to the performance of the transmission lines against lightning strike. Indonesian state electricity company and other private company in Indonesia supply their electricity power using high voltage and extra high voltage transmission lines. To protect these transmission lines against lightning strikes, conventional lightning protection system are used. Due to their different lightning characteristic, the damage on the insulators on transmission towers, earth wire and transmission lines arrester that lead to power system outages are reported. Some innovative technology based on researches carried out in Lightning Measurement Station in Mnt Tangkuban Perahu and several research areas in Indonesia are now installed to improve the lightning protection in transmission lines. Some significant improvements are reported.
\end{abstract}

Keywords: Lightning current parameters, insulator damages, conventional protection system, extended mast terminal.

\section{Introduction}

Indonesia is located in the tropics and have a lot of islands and rain forest. With these conditions, the cumulonimbus (CB) cloud that produce thunderstorm lightning is very easy to develop. Damages due to lightning strikes always take place not only in the power utility area but also on the oil and gas company, transportation, industries, military equipment and installation, rail road communication and signal system and many other installations all over Indonesia are reported year by years.

Lightning research was carried out since 1992 in Mnt. Tangkuban Perahu, West Java and Indonesia Lightning detection system (Jaringan Deteksi Petir Nasional/ JADPEN) were built and operated by Institute of Technology Bandung (ITB) since 1995 to observe the lightning activity and to study lightning parameters in the tropics.

Two most importance lightning current parameters were derived from the measurement, which are peak lightning current (i) and steepness of the lightning wave current (di/dt) which give the significant impact for the protection of Transmission Lines against lightning strikes. Strikes to towers and earth wire will produce Back Flashover (BFO) on the insulators and lightning direct strikes to phase wire will develop the travelling wave that can lead to insulator damages, called Shielding Failures (SF).

Conventional way as stated on the standard and text book has been applied for long time [5], but due to tropical condition and that the protection system was also not properly installed, it was not fully succeeded, especially due to the facts that lightning produce very high voltage on the towers. The research on tropical lightning current parameters has led to the conclusion that the tower characteristic is not allowed to be "read" by the lightning current steepness to prevent very high voltages due to their inductance on the tower that can lead to BFO. An innovative technology called extended mast terminal and free-standing mast are applied since 2005 at the towers on HV and EHV lines at state electricity company (PLN) all over Indonesia.

Received: July $16^{\text {th }}, 2019$. Accepted: August $15^{\text {th }}, 2019$

DOI: 10.15676/ijeei.2019.11.3.4 


\section{Lightning Current Parameters}

Measurement of lightning current parameter was carried out in Mnt. Tangkuban Perahu and by using lightning detection system for more than 8 years. Most of lightning data derived from the lightning location system and calibration of these data was carried out by measuring the lightning peak current that hit the 106-meters tower recorded by Magnetic tape peak current measurement system [1]. This 106-meters high tower was equipped with instrumentations that can measured the lightning waveform by using transient recorder, lightning event counter and magnetic tape. $50 \%$ amplitude probability of lightning current derived from this measurement is $40 \mathrm{kA}$ and compare to the measurement derived from Prof Berger at Monte Salsavatore in Switzerland, a sub-tropical area, is $30 \mathrm{kA}$ for total lightning current and for negative current only $18 \mathrm{kA}[2]$, as shown in figure 1 and 2.

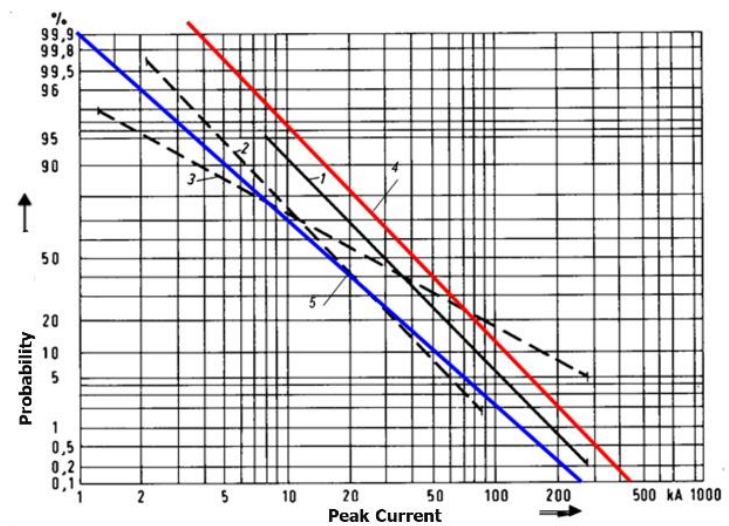

Figure 1. Lightning Peak Current Parameters, measured by Prof. Berger at Mnt. San Salvatore, Switzerland for sub- tropical lightning (black) and measured by Prof. Zoro in Mnt. Tangkuban Perahu, Indonesia (blue-red)

Lightning peak current will produce the voltage rise on the earthing system (Rimpuls). The steepness of lightning current (di/dt) is measured and given in the following figures [2].

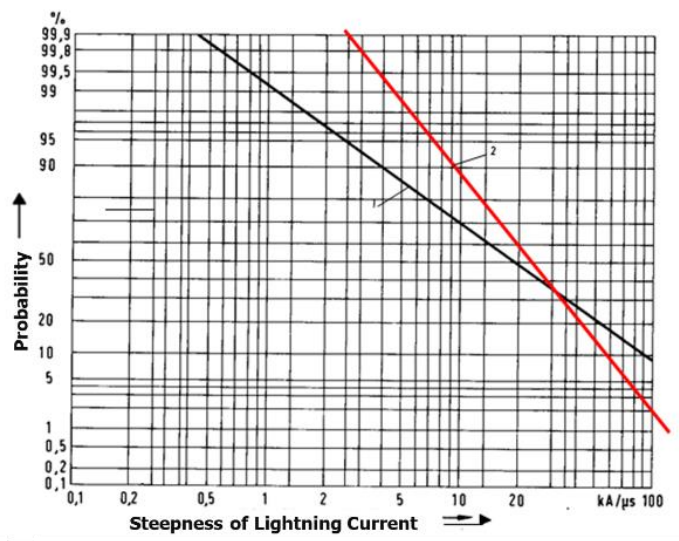

Figure 2. Steepness (di/dt) of Lightning Current measured by Berger (black) and Zoro (red)

Steepness of lightning current derived from this measurement at $50 \%$ probability is $18 \mathrm{kA} / \mu \mathrm{s}$ for sub tropics and $25 \mathrm{kA} / \mu$ s for tropical area. Due to the inductance of the tower, this current steepness will produce high voltage at the tower structure and together with the voltage appears at the grounding system (RE) and the total voltage will lead to BFO on the insulators.

$\mathrm{V}_{\mathrm{M}}=\mathrm{i}_{\mathrm{S}} . \mathrm{R}_{\mathrm{E}}+\mathrm{L} \cdot \mathrm{di} / \mathrm{dt}+\mathrm{V}_{\mathrm{L}}$ 
Where $V_{M}$ is voltage stress due to lightning strike to tower, $I_{S}$ is lightning peak current, di/dt is the lightning current steepness, $\mathrm{L}$ is tower inductance, $\mathrm{R}_{\mathrm{E}}$ is tower footing resistance and $\mathrm{V}_{\mathrm{L}}$ is instantaneous voltage of the system.

Table 1 below shows the summary of lightning characteristic in Indonesia.

Table 1. Summary of lightning characteristic in Indonesia ${ }^{[2]}$

\begin{tabular}{|c|c|c|c|c|}
\hline \multicolumn{3}{|c|}{ Lightning Characteristic } & $\begin{array}{l}\text { Negative } \\
\text { Polarity } \\
\end{array}$ & $\begin{array}{l}\text { Positive } \\
\text { Polarity } \\
\end{array}$ \\
\hline \multirow{4}{*}{$\begin{array}{c}\text { Peak } \\
\text { Current (i) }\end{array}$} & \multirow{2}{*}{ Maximum } & T. Perahu & $280 \mathrm{kA}$ & $298 \mathrm{kA}$ \\
\hline & & Jawa Barat & $335 \mathrm{kA}$ & $392 \mathrm{kA}$ \\
\hline & \multicolumn{2}{|c|}{ Probability $50 \%$} & $40 \mathrm{kA}$ & $18 \mathrm{kA}$ \\
\hline & \multicolumn{2}{|c|}{ Average } & $41 \mathrm{kA}$ & $30 \mathrm{kA}$ \\
\hline \multirow{2}{*}{$\begin{array}{c}\text { Steepness } \\
\text { (di/dt) }\end{array}$} & \multicolumn{2}{|c|}{ Maximum $(\mathrm{kA} / \mu \mathrm{s})$} & 119 & 120 \\
\hline & \multicolumn{2}{|c|}{ Probability $50 \%(\mathrm{kA} / \mu \mathrm{s})$} & 30 & 20 \\
\hline \multicolumn{3}{|c|}{ Flash Density (strikes/km²/year) } & $4,1-12,4$ & $1,5-3,8$ \\
\hline \multicolumn{3}{|c|}{ Flash Density total (strikes $/ \mathrm{km}^{2} /$ year) } & \multicolumn{2}{|c|}{$7,9-15,5$} \\
\hline
\end{tabular}

Tower equivalent inductance (L) on $\mu \mathrm{H} / \mathrm{m}$ can be derived from curve given on figure 3 .

Typical inductance of tower structure for transmission lines is around $1 \mu \mathrm{H} / \mathrm{meter}$ and tower footing resistance is $10 \Omega[3]$.

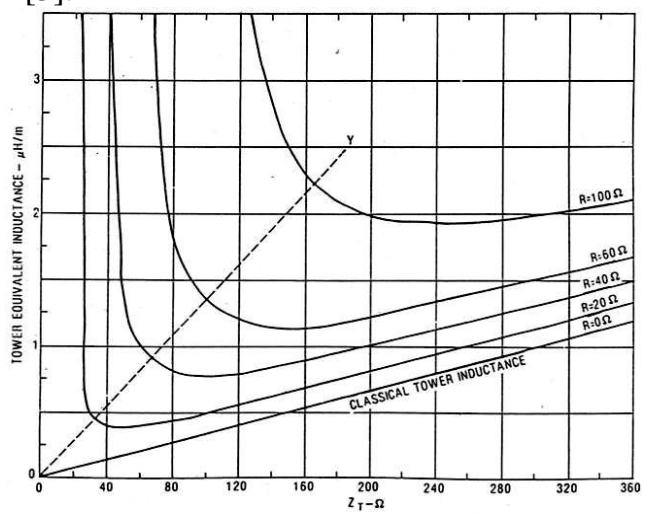

Figure 3. Tower Inductance depends on tower impedance and grounding resistance

\section{Insulators Damage}

Insulators damages in transmission lines caused by BFO and SF. Back flashover due to direct lightning strikes to the tower or earth wire and shielding failures caused by direct lightning strike to phase wire and produce travelling wave to both side of the phase wire and cause damages on insulator strings.

Most of transmission line insulators in Indonesia operated with 12 disc of strings insulators. It has basic insulation level (BIL) of $1105 \mathrm{kV}$ [5].

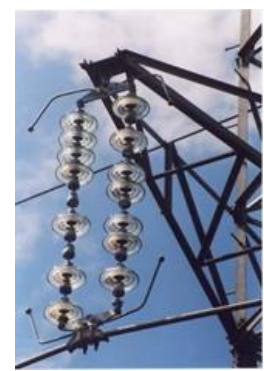

Figure 4. Insulators equipped with arcing horn and damages due to back flash over or shielding failures on $150 \mathrm{kV}$ lines 
Figure 4 shows that insulator damages due to Back Flashover or Shielding Failures.

Lightning direct strikes cause more problems in high voltage and Extra High Voltage Transmission lines. Strikes at phase conductor may result flashover at insulators, and strikes at transmission tower or earth wire may result back flashover. Statistically as reported by State Electricity Company of Indonesia (PLN) $500 \mathrm{kV}$ lines have the statistically of $30 \%$ of outage caused by lightning, $49 \%$ for $150 \mathrm{kV}$ lines and more than $60 \%$ on $70 \mathrm{kV}$ lines.

\section{Conventional Lightning Protection System for Transmission Lines}

To overcome the problems, several protection systems against lightning strikes that normally installed for transmission lines protections have been installed and operated and these are;

1. Installation of additional one or two disc on insulators strings at the transmission lines to achieve better improvement and less insulators damages on the line is reported. The problem is more BIL of insulators will produce higher incoming travelling wave from the line entering substations. Nowadays the electric company use 12 Disc insulators for $150 \mathrm{kV}$ lines with Basic Insulation Level of $1105 \mathrm{kV}$ [4]. It should have only 8 to 10 disc. Higher travelling wave will enter the substation and give more stress to the equipment and insulation coordination will not be good because the system become expensive [5].

2. New additional earth wire at the transmission tower will separate the lightning impulse current that hit the earth wire and tower to 3 for 1 earth wire, 5 or 7 for two or three earth wire, including impulse current that will flow to the grounding system through the tower. According to equation (1), by reducing the amplitude of the lightning impulse current, the voltage at the grounding system will be lower. Very interesting to know that the steepness of the lightning current remains almost the same, it means the voltage appears at the tower due to tower inductance and the steepness still give very high voltage to the tower that can be higher than insulators impulse strength.

\section{THREE OHGW 275 kV Siguragura-Kualatanjung}

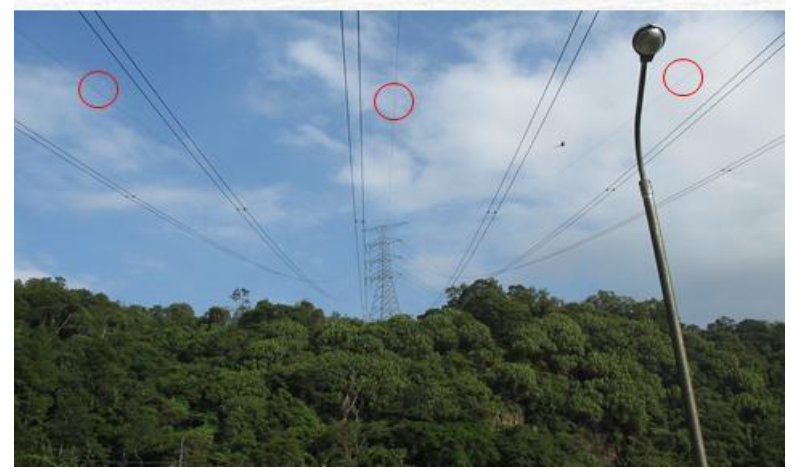

Figure 5. Three earth wire to reduce lightning peak current flow to the tower grounding.

3. The problem of shielding failures (SF) can be overcome by installing the transmission lines arrester (TLA) to protect the insulators strings. It was reported that a lot of TLA was fail to operate and some others was damage. Most of the TLA was installed in the two lower phase wire of the transmission lines since the highest overvoltage appeared at the top phase [8]. Some reason of the damage of TLA is due to improper installation, such as; protection distance problems and high steepness of lightning impulse current. Transmission Line Arrester has to be installed as close as possible to the protected object or insulators. The protected distance depends only to the steepness of the incoming lightning current impulse wave. 


$$
\mathrm{L}=\frac{\mathrm{Ut}-\mathrm{Ula}}{2 \frac{\mathrm{du}}{\mathrm{dt}}} \mathrm{V}
$$

Where:

$\mathrm{du} / \mathrm{dt}=\mathrm{Z} \cdot \mathrm{di} / \mathrm{dt}$

$\mathrm{L}$ is the protection distance (plus arrester lead), $\mathrm{U}_{\mathrm{t}}$ is the insulation level strength of protected object (BIL), $\mathrm{U}_{\mathrm{la}}$ is Voltage discharge of Arrester, du/dt is voltage steepness, $\mathrm{Z}$ is surge impedance and $\mathrm{v}$ is speed of light $=300 \mathrm{~m} / \mathrm{us}$ and di/dt is lightning current steepness.

Surge impedance of phase wire is around $300 \mathrm{ohms}, 350 \mathrm{ohms}, 400 \mathrm{ohms}, 450 \mathrm{ohms}$ and 500 ohms for overhead transmission lines of $70 \mathrm{kV}, 150 \mathrm{kV}, 275 \mathrm{kV}$ and $500 \mathrm{kV}$ respectively [5,9]. For $50 \%$ steepness probability of $25 \mathrm{kA} / \mathrm{us}$ the protection distance or maximum lead of the arrester will become $7 \mathrm{~m}, 10 \mathrm{~m}, 18 \mathrm{~m}$ and $28 \mathrm{~m}$. For $10 \%$ steepness probability of $70 \mathrm{kA} / \mathrm{us}$ will become; $3 \mathrm{~m}, 4.6 \mathrm{~m}, 8 \mathrm{~m}$ and $12 \mathrm{~m}$, since the protection distance is strongly depended on lightning current steepness.

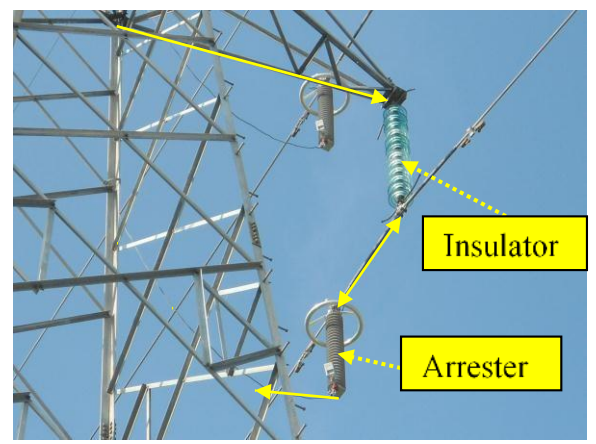

Figure 6. Protection distance (L) of Transmission Line Arrester (TLA) at $150 \mathrm{kV}$ tower.

Figure 6 shows the protection distance of TLA at $150 \mathrm{kV}$.

4. Improvement of the grounding system of the tower are of the most popular in power system. The measurement of earth resistance is normally being done by DC earth tester and it will give the different results if the structure when it is hit by impulse current. The value of the impulse earth resistance of the tower depends on the steepness of the lightning current. The best grounding system is foundation grounding, when the structures are not built yet, it will give lower and then best grounding impedance when the steepness is higher [3]. The application of foundation grounding can be seen in figure 7 .

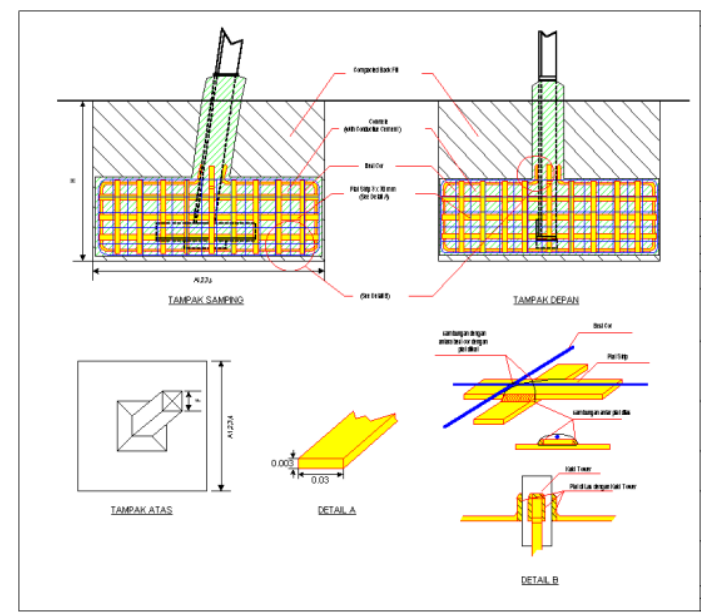

Figure 7. Foundation grounding for transmission tower: Additional galvanized steel plate welded to the foundation rebar. 
For existing tower grounding system additional counterpoises system is recommended. The newly installation for lightning protection of $150 \mathrm{kV}$ transmission line is being done by installation of the additional bare copper of $50 \mathrm{~mm}^{2}$ down conductor attached to the tower to the grounding system which is isolated by $20 \mathrm{kV}$ insulator or directly connected from the earth wire to the grounding system.

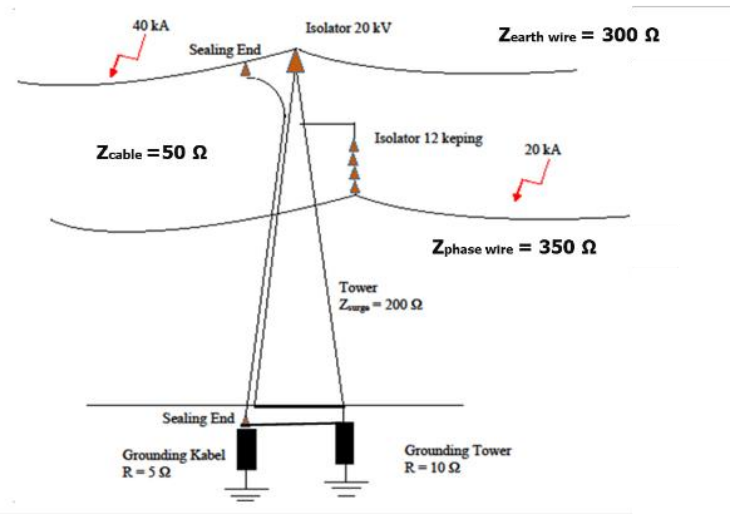

Figure 8. Illustration of direct strike to tower and to phase wire

Figure 8 shows the illustration of direct strike to tower and phase wire. Due to surge impedance of earth wire, lightning strike will produce high voltage on the earth wire $(20 \mathrm{kA} \mathrm{x}$ $300 \mathrm{ohm}=6000 \mathrm{kV}$ ) and it will produce flashover at $20 \mathrm{kV}$ insulator which has only $125 \mathrm{kV}$ BIL. If bare copper conductor of $50 \mathrm{~mm}^{2}$ is connected directly to ground, it has no or a little influence to the existing tower surge impedance. If a cable is used breakdown at sealing end cable will take place. Additional earth wire will divide only the lightning peak current but not the di/dt (equation 1). This system gives no improvement for the protection of transmission lines against lightning strikes.

Most of the protection system mentioned above have already applied but there are still problems reported. To get the better \& reliable protection system the work has to be done by improving the existing installed protection system and introducing the innovative technology based on the research results carried out at Lightning Measurement Station and field test at several areas of transmission line and communication towers in Indonesia [5,10].

\section{Innovation technology for protection of Transmission Line Towers}

Refer to the equation (1) given above, the main problem to minimize the flashover (BFO) at insulators of the tower is not only depends on the impulse resistance of the grounding system but mostly depends to the inductance of the tower, since peak current amplitude and the lightning current steepness in tropical area is given and measured. At every 1 meter of the tower structure will give almost $1 \mu \mathrm{H}$ with grounding resistance of $20 \mathrm{ohms}$ and the tower surge impedance is $260 \mathrm{ohms}$ (figure 3). It is impossible to reduce $\mathrm{L}$ of the tower by using additional earth wire connected directly to the grounding system since the inductance value is still remain the same. To reduce or to minimize the tower inductance $(\mathrm{L})$ is to let the current flow not through the tower structure but to "force" the lightning current flow inside a low inductance cable. It means the finial or lightning rod has to be higher than the tower structure and easy to be hit by lightning. At the other end of cable is connected to the existing tower grounding system.

The cable is connected to air terminal isolated from the tower by using Reinforced Plastic Fiber around 2 meters long. In order to be easily hit by the lightning, an early streamer emission air terminal is used and the extension of air terminal is supported by 8 to 12 meters long galvanized steel pipe installed at the top of the tower. The inductance of the cable is less than $0.03 \mu \mathrm{H} / \mathrm{m}$. This innovation system called Extended Mast Terminal or EMT (7). The installation and construction of EMT can be seen at figure 9 and figure 10 . 


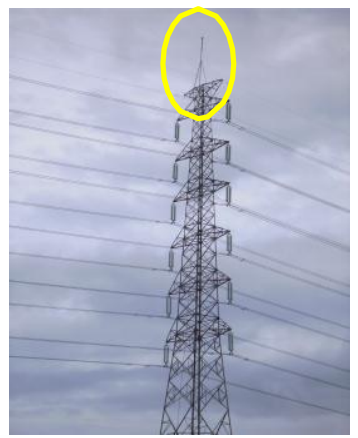

Figure 9. EMT at $150 \mathrm{kV}$ Line in Batam Island

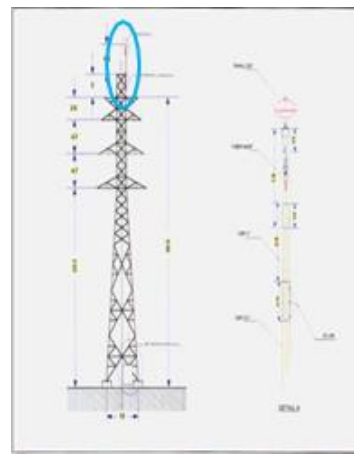

Figure 10. Construction of EMT at $150 \mathrm{kV}$ lines

Lightning strike will hit the air terminal and let the lightning current flow inside the cable with low inductance to the grounding system isolated from the tower structure. The voltage arise at the grounding system is almost $1 / 30$ of the voltage without cable and prevent the back flashover at the insulator's tower. Field test has already done at $500 \mathrm{kV}$ tower in east Java with very significant results [12]. Installation of this technology have already applied at $70 \mathrm{kV}$ lines in West Java, $150 \mathrm{kV}$ lines at Kalimantan and $150 \mathrm{kV}$ lines in Batam island.

Lightning strike to the phase wire that can lead to shielding failures have to be protected with the Transmission Lines Arrester (TLA) with the proper installation. The figure 11 shows the installation of TLA with minimum protected distance.

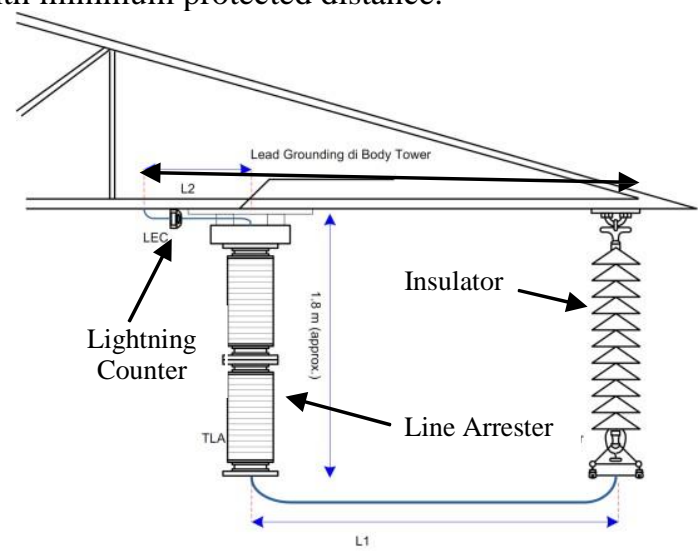

$\mathrm{L} 1+\mathrm{L} 2 \leq 3.72 \mathrm{~m}$

Figure 11. Installation of TLA at $150 \mathrm{kV}$ line with minimum protected distance 
The newly introduce to Indonesia is the multi chamber insulating arrester that use also as insulators [16]. There is no problem with the protection distance since it acts also as insulators. Some arrester of this type is now being tested in $20 \mathrm{kV}$ line in Serpong area, south of Jakarta Indonesia since 2013 [16].

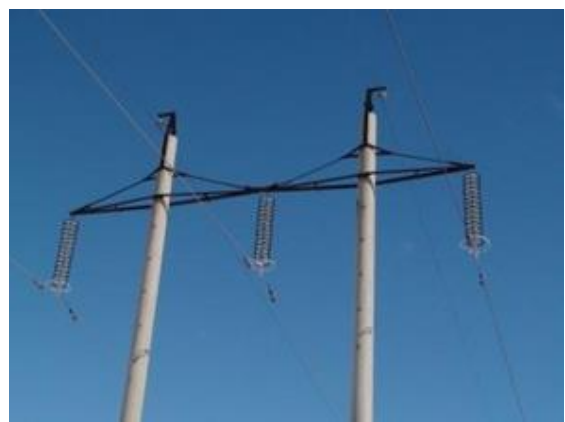

Figure 12. Multi Camber Insulating Arrester - MCIA at $110 \mathrm{kV}$ line outside Indonesia

The figure 12 shows the Multi Chamber Insulating Arrester at $110 \mathrm{kV}$ Line outside Indonesia. The advantages of this system for HV and EHV have to be proved especially in tropical condition to overcome the problem of back flashover and shielding failures on insulator strings of transmission lines.

\section{Conclusion}

Amplitude and steepness of tropical lightning current characteristic give the influence at the voltage produce at the tower of transmission lines.

Main problem due to lightning strikes is back flashover when the lightning hit the tower and earth wires and the other problems is shielding failures that will take place when the lightning hit directly to phase wires.

Since inductance of the tower structures plays an important role due to high steepness of lightning current to produce high voltage that can damage the insulators the use of low inductance cable is very important

Shielding failures can be minimized by improper installation of transmission line arrester and installation of the new multi chamber insulating arrester.

\section{References}

[1] Zoro, R (1997), Calibration of Lightning Detection System by using magnetic tape measurement system at 106meter high tower at Mnt. Tangkuban Perahu, West Java, Indonesia.

[2] Zoro, R. (1999), Lightning Characteristic and weather condition in the tropics, Mnt. Tangkuban Perahu case in Indonesiam, PhD Dissertation, Institut Teknologi Bandung Indonesia.

[3] IEC 62305-1/2006 - Standard for LightningcProtection System.

[4] Zoro, Reynaldo, "Lightning Protection in Electrical System", PT Remaja Rosdakarya, Bandung, 2018.

[5] Hileman, A.R., "Insulation Coordination for Power Systems", Marcel Dekker, Inc., New York, 1999.

[6] IEEE 1243-1997 Guide for Improving Lightning Performance of Transmission Lines" Institute of Electrical and Electronics Engineers, Inc, 1997.

[7] Zoro R, Tulus Leo.S "Lightning Protection Improvement on the transmission Lines using Extended Mast Terminal" 5th Rusian Conference on Lightning Protectionm, May 17-19, St Petersburg, Rusia, 2016.

[8] Chowduri, Transient Analysis on Power System, text book of CRC.

[9] Zoro.R. "Overvoltages on Electric power system"lecture Note, Penerbit ITB, 1995 
[10] Zoro, R; Nawawi Z; "Lightning protection system for Telecommunication tower at Mnt. Tangkuban Perahu, West Java, Indonesia" International Lightning Conference, Williamsburg, United State of America, 1995.

[11] Eko Yudo Pramono; Zoro, Reynaldo, "Evaluation of Lightning Protection System for 500 kV EHV Lines", International Conference on Electrical Engineering and Informatics ICEEI, Kuala Lumpur Malaysia, 2008.

[12] IEEE Guide for Improving Lightning Performance of Electric Power Distribution Lines, IEEE Standard 1410- 1997, IEEE Power Society, New York, 1997.

[13] Hidayat, S. et al, "Daily Activity Pattern of Lightning in Java Island", The Indonesian Journal on HV Eng. Vol. 1 No. 1, 1999.

[14] Zoro, R. et al, "Analysis of Lightning Characteristics and Climate in Tropical Area", The Indonesian Journal on HV Eng. Vol. 2 No.2, 2000.

[15] Reynaldo Zoro, Tulus Leo, Syarif Hidayat "Lightning Protection for Medium Voltage Overhead Distribution Lines in High Lightning Density Area" 5th Russian Lightning Protection Conference, 17-19 May, St.Petersburg, Rusia, 2016.

[16] Zoro, R. et al, "Lightning Protection and Grounding System for transmission and distribution line in the tropical country" Training Course, September 18th-20th, Bandung, Indonesia, 2018

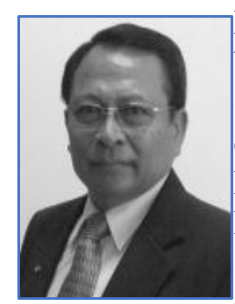

Reynaldo Zoro was born in Sawahlunto (Indonesia) on 1950. He received the bachelor degree of electrical engineering from Institute of Technology Bandung (ITB), Indonesia in 1976. He got his Dipl. Ing. degree from Technical University of Munich in 1982. At 1999 he received a doctor degree on Science from ITB Postgraduate School.

He is a senior lecturer at School of Electrical Engineering and Informatics, ITB since 1978 and become Professor in Lightning Detection and Protection System of ITB since 2013. He is a member of ITB"s Power Engineering Research Group since 2006, member of High Voltage and High Current Engineering Laboratory and head of Lightning Measurement Station at Mt. Tangkuban Perahu, owned and operated by ITB. He is a Scientific Chairman of Indonesian Lightning Society since 2008. He is a current member of IEC -TC 81 since 1995 and individual member of CIGRE since 1998. Chairman of Lightning Research Center of SEEI of ITB since 2011. He is now a member of Mirror Committee for IEC TC 81developed by Indonesian Berau of Standardization or BSN since June 2016. Zoro is a researcher and his current field of research is in the lightning protection and detection system, tropical lightning and atmospheric electrodynamics. 